\title{
RICE CULTIVATION IN AMUR REGION
}

\author{
E.P. Borovoy ${ }^{1}$, M.V. Makannikova ${ }^{2}$, L.A. Lapshakova ${ }^{2}$ \\ ${ }^{1}$ Volgograd State Agricultural University \\ Universitetskiy pr., 26, Volgograd, 400002, Russian Federation \\ ${ }^{2}$ Far East State Agrarian University \\ Kuznechnaya str., 95, Blagovetschensk, 675000, Russian Federation
}

\begin{abstract}
Rice plays an important role in the modern diet of Russian people. It occupies a leading position in area, yield, and gross grain harvest among all cereal crops. The aim of the research is development of optimal irrigation regimes that ensure rational use of water resources in southern agricultural zone of Amur Region. Setting and conducting field and laboratory experiments, system approaches and modern research methods were used. The article presents the results of studies on rice cultivation under different irrigation regimes. In the southern zone of Amur Region, along with water regimes of 70, 80, 90\% of FMC, differentiated rice irrigation regimes were studied, combining differentiation of presumed humidity thresholds and wetting depth of active soil layer $75 \ldots 85 \%$ of FMC $(0.4$ and $0.6 \mathrm{~m}) ; 80 \%$ of FMC $(0.4$ and $0.6 \mathrm{~m})$. In addition, various flooding regimes of rice field (short and intermittent flooding), seeding rates, timing of sowing, rice cultivars were studied. Obtaining a rice grain yield of more than 4 tons per hectare is ensured by application of mineral fertilizers in the dose of $\mathrm{N}_{120} \mathrm{P}_{30} \mathrm{~K}_{30}$ and seeding rate of 5 million seeds. Optimum seeding time was set from 20 to 25 May. Based on the results of the research, irrigation water was saved, as well as yield increased by optimizing irrigation rice regimes using sprinkling by differentiating presumed moisture thresholds and wetting depth. When rice was cultivated under flooding system of irrigation, it was established that regime of shortened flooding turned to be optimal. When sprinkling in conditions of southern agricultural zone of Amur Region, differential irrigation regime of $75 \ldots 85 \%$ of FMC in active soil layer was 0.4 and $0.6 \mathrm{~m}$.
\end{abstract}

Keywords: rice, water regimes, sprinkling, flooding, fertilizer doses, seeding rates, varieties

\section{INTRODUCTION}

Rice is one of the most important crops in diet of Russian people. It occupies a leading position in area, yield, and gross grain harvest among all cereal crops. The demand for rice is increasing every year. Growth and stabilization of grain production in Amur region can help in solving problem of providing the population with own grain by increasing crop diversity. Amount of heat and light in the southern zone of Amur Region is sufficient to cultivate rice. Rice cultivation can contribute to increasing grain production in the area. According to the Ministry of Agriculture of the Russian Federation, area suitable for cultivating rice in the Far East is at least 240 thousand hectares. Thus, not only the population of this region, but also all of Eastern Siberia, can be provided with rice grains [1-3]. Currently in the Far Eastern Federal District rice is cultivated only in Primorsky region, but production is not enough to meet the growing food needs of the Far East [4]. Therefore, the relevance of our research is determined 
by the need to develop effective water regimes for rice cultivation in compliance with principles of water conservation and environmental safety requirements of production.

The aim of the research is the development of optimal irrigation regimes that ensure rational use of water resources in the southern agricultural zone of Amur Region.

\section{MATERIALS AND METHODS}

Field research has been conducted since 2005 on experimental field of Far East State Agrarian University, p. Gribskoye of Blagoveshchensk district of Amur region, located in the zone of Gribskoye irrigation system. Observations and records have been documented, while observing the requirements of techniques of the experimental case [5-7]. We studied water regime of soils: pre-irrigation soil moisture content of $70,80,90 \%$, $75-85 \%$ of field moisture capacity (FMC) $(0.4$ and $0.6 \mathrm{~m}) ; 80 \%$ of FMC $(0.4$ and $0.6 \mathrm{~m}) ; 80 \%$ of FMC $(0.6 \mathrm{~m})$ (control) — sprinkling, shortened flooding: creating a water layer of $0.10 \ldots 0.12 \mathrm{~m}$ after sowing, after $0.10 \ldots 0.12 \mathrm{~m}$ seedlings till tillering phase, decreasing water layer to $0.05 \mathrm{~m}$ before tubing phase, increasing water layer to $0.15 \mathrm{~m}$ until the end of milk ripeness (control); intermittent flooding: after sowing $0.10 \mathrm{~m}$ (10 days), then water removing, after emergence $0.07 \mathrm{~m}$ (2...3 days), water removing, then $0.10 \ldots 0.12 \mathrm{~m}$ and maintained till tillering phase, water layer decreasing up to $0.05 \mathrm{~m}$ (10 days), increasing water layer to $0.15 \mathrm{~m}$ and maintaining until the end of grain ripeness; intermittent flooding: creating a layer of water $0.12 \mathrm{~m}$ after sowing, no water in rice field during 7 days, on the 8 th day the whole cycle repeats. Then $0.10 \ldots 0.12 \mathrm{~m}$ to tillering phase, followed by a water decreasing to $0.05 \mathrm{~m}$ (10 days), further increasing water layer to $0.15 \mathrm{~m}$ and maintaining till the end of grain milky ripeness. Fertilizer doses were control without fertilizers; $\mathrm{N}_{60} \mathrm{P}_{30} ; \mathrm{N}_{90} \mathrm{P}_{30} \mathrm{~K}_{15} ; \mathrm{N}_{120} \mathrm{P}_{30} \mathrm{~K}_{30}$. Seeding rates were 4 million (control); 5 and 6 million of seeds. Rice cultivars: dry-bottomed (early cultivar 'Volgogradskiy' of Research Institute of Irrigated Agriculture, high-yielding, resistant to sharply continental climate), and rice cultivars regionalized in Primorsky Krai, which are related to early ripening groups: round-grained - 'Dariy 23', 'Priozerny 61'; longgrained — 'Khankaisky 429', 'Khankaisky 52', 'Lugovoy', 'Rassvet' and 'Kaskad' with high technological and culinary quality. Sowing terms: $10.05-15.05 ; 20.05-25.05$; $30.05-04.06$.

The soil cover of the site is represented by meadow-brown soils. The density of soil in calculated layers $(0.6 \mathrm{~m})$ is $1.33 \mathrm{t} / \mathrm{m}^{3}$, the lowest moisture capacity of the soil is $22.50 \%$, porosity is $49.18 \%$. Humus content is low $2.13 \%$, easily hydrolyzable nitrogen is $2.7 \mathrm{mg} / 100 \mathrm{~g}$, mobile phosphorus content is $37.8 \mathrm{mg} / \mathrm{kg}$, exchange potassium content is $122.5 \mathrm{mg} / \mathrm{kg}$.

The years of research differed significantly in the magnitude and distribution of atmospheric precipitation, which made it possible to assess effectiveness of the irrigation regimes studied.

Rice cultivation in field experiments was carried out on the basis of existing zonal recommendations supplemented by variants of studied methods. To control weed vegetation a broad spectrum post-emergence herbicide Segment was used. 
Phenological observations of rice growth stages, plant density, determination of crop structure by the method of Gossortoseti (1995), photosynthetic indicators of crops according to the method of A.A. Nichiporovich $(1979,1985)$ were carried out in the field experiments. Humus content was determined by the method of I.V. Tyurin and B.A. Nikitin in the modification of CINAO in accordance with GOST 26213-84, aqueous and salt $\mathrm{pH}$ - according to potentiometric method in accordance with GOST 26483-90, total nitrogen - according to Kornfeld, easily hydrolyzed nitrogen — by the method of M.M. Konova and I.V. Tyurin, mobile phosphorus and potassium - according to B.P. Machigin - GOST 26205-91. In determining water-physical properties of the soil granulometric composition was studied according to the method of N.A. Kachinsky, density of solid phase - pyknometric method, soil density — method of cutting ring, and field moisture capacity (FMC) — by flooded areas.

Analyzes for determination of water-physical and agrochemical properties of soils were carried out in agrochemical laboratory of Department of Ecology and Soil Science of Far East State Agrarian University and in laboratory of Soybean Research Institute.

Weed infestation of seedlings and before harvesting was carried out by applying a marking $-0.25 \mathrm{~m}^{2}$ in 10 replicates. Water balance calculations for rice checks were carried out according to the method of Rice Research Institute (1979). Total water consumption — by A.N. Kostyakov (1975).

\section{RESULTS AND DISCUSSION}

We found that irrigation frequency varied during experimental years, depending on irrigation regime and cultivar $[6,7]$.

To maintain soil moisture at the level of $70 \%$ of FMC depending on meteorological conditions in 2005-2007 it was required to conduct 5...8 waterings with a rate of $670 \mathrm{~m}^{3} /$ ha. Increase in pre-irrigation humidity threshold to $80 \%$ of FMC was accompanied by increase in number of waterings to $8 \ldots 12$ with irrigation rate of $450 \mathrm{~m}^{3} / \mathrm{ha}$. Maintenance of $90 \%$ of FMC in calculated soil layer was achieved by $11 \ldots 15$ waterings with a rate of $220 \mathrm{~m}^{3} /$ ha. In 2008, all irrigation water for entire growth season was used during 8 waterings, in 2009 — during 6 waterings and in 2010 — during 10 waterings (Table 1).

Total water consumption of irrigated rice under different weather conditions varied from $6,179 \ldots 9,199 \mathrm{~m}^{3} /$ ha. The greatest average for research years was noted in the variant with maintaining soil moisture of at least $90 \%$ of FMC and amounted to $8630 \mathrm{~m}^{3} / \mathrm{ha}$.

As field studies showed, the most favorable for rice cultivation in terms of water availability was 2013, when precipitation during the growing season was $166 \mathrm{~mm}$ higher. In the variant of differentiated moistening in 2013, it was necessary to conduct 2 vegetative waterings with irrigation rate $560 \mathrm{~m}^{3} /$ ha for cultivar 'Khankaisky 429' and $530 \mathrm{~m}^{3} /$ ha for cultivar 'Rassvet'. In 2011, in the same variant, it was necessary to conduct 8 watering operations with the rate of $2,060 \mathrm{~m}^{3} /$ ha for cultivar 'Khankaiskiy 429', 6 waterings with the rate of $1560 \mathrm{~m}^{3} /$ ha for cultivar 'Rassvet'; in 2012 , irrigation rate was $1,810 \mathrm{~m}^{3} /$ ha and $1,560 \mathrm{~m}^{3} /$ ha for 'Khankaiskiy' and 'Rassvet', respectively (Table 2 ). 
The structure of rice total water consumption, 2005-2010

\begin{tabular}{|c|c|c|c|c|c|c|c|c|}
\hline \multirow{2}{*}{$\begin{array}{l}\text { Pre- } \\
\text { irrigation } \\
\text { moisture, } \\
\% \text { of FMC }\end{array}$} & \multirow[t]{2}{*}{$\begin{array}{l}\text { Research } \\
\text { years }\end{array}$} & \multirow{2}{*}{$\begin{array}{l}\text { Total water } \\
\text { consumption } \\
(E), \mathrm{m}^{3} / \mathrm{ha}\end{array}$} & \multicolumn{2}{|c|}{ Irrigation Rate } & \multicolumn{2}{|c|}{$\begin{array}{l}\text { Precipitation } \\
\text { moisture }\end{array}$} & \multicolumn{2}{|c|}{$\begin{array}{l}\text { Soil moisture } \\
\text { reserves }\end{array}$} \\
\hline & & & $\mathrm{m}^{3} / \mathrm{ha}$ & $\%$ of $E$ & $\mathrm{~m}^{3} / \mathrm{ha}$ & $\%$ from $\mathrm{E}$ & $\mathrm{m}^{3} / \mathrm{ha}$ & $\%$ from $\mathrm{E}$ \\
\hline \multirow[t]{4}{*}{70} & 2005 & 7585 & 5460 & 72.0 & 2050 & 27.0 & 75 & 1.0 \\
\hline & 2006 & 8680 & 3450 & 39.7 & 5110 & 58.9 & 120 & 1.4 \\
\hline & 2007 & 8635 & 5460 & 63.2 & 3070 & 35.6 & 105 & 1.2 \\
\hline & average & 8300 & 4790 & 58.3 & 3410 & 40.5 & 100 & 1.2 \\
\hline \multirow[t]{7}{*}{80} & 2005 & 7640 & 5510 & 72.1 & 2050 & 26.8 & 80 & 1.1 \\
\hline & 2006 & 8945 & 3710 & 41.5 & 5110 & 57.1 & 125 & 1.4 \\
\hline & 2007 & 8900 & 5720 & 64.3 & 3070 & 34.5 & 110 & 1.2 \\
\hline & 2008 & 6885 & 4270 & 62.0 & 2415 & 35.1 & 200 & 2.9 \\
\hline & 2009 & 6179 & 2700 & 43.7 & 3325 & 53.8 & 154 & 2.5 \\
\hline & 2010 & 8587 & 4450 & 51.8 & 4962 & 57.7 & 125 & 1.4 \\
\hline & average & 7856 & 4393 & 55.9 & 3488 & 44.1 & 132 & 1.8 \\
\hline \multirow[t]{4}{*}{90} & 2005 & 7931 & 5810 & 73.3 & 2050 & 25.8 & 71 & 0.9 \\
\hline & 2006 & 9199 & 3970 & 43.2 & 5110 & 55.5 & 119 & 1.3 \\
\hline & 2007 & 8760 & 5590 & 63.8 & 3070 & 35.0 & 100 & 1.2 \\
\hline & average & 8630 & 5123 & 60.1 & 3410 & 38.8 & 96.7 & 1.1 \\
\hline
\end{tabular}

The structure of total water consumption of rice varieties

Table 2 under different sprinkler irrigation regimes

\begin{tabular}{|c|c|c|c|c|c|c|c|c|}
\hline \multirow{2}{*}{$\begin{array}{l}\text { Pre-irrigation } \\
\text { moisture, \% of } \\
\text { FMC }\end{array}$} & \multirow[t]{2}{*}{$\begin{array}{l}\text { Research } \\
\text { years }\end{array}$} & \multirow{2}{*}{$\begin{array}{l}\text { Total water } \\
\text { consumption } \\
(\mathrm{E}), \mathrm{m}^{3} / \mathrm{ha}\end{array}$} & \multicolumn{2}{|c|}{ Irrigation Rate } & \multicolumn{2}{|c|}{$\begin{array}{l}\text { Precipitation } \\
\text { moisture }\end{array}$} & \multicolumn{2}{|c|}{$\begin{array}{l}\text { Soil moisture } \\
\text { reserves }\end{array}$} \\
\hline & & & $\mathrm{m}^{3} / \mathrm{ha}$ & $\%$ of $E$ & $\mathrm{~m}^{3} / \mathrm{ha}$ & $\%$ of $E$ & $\mathrm{~m}^{3} / \mathrm{ha}$ & $\%$ of $E$ \\
\hline \multirow{10}{*}{$\begin{array}{l}\text { Variant } 1: \\
75 \% \ldots 85 \% \text { of } \\
\text { FMC, } \\
0.4 \text { and } 0.6 \mathrm{~m}\end{array}$} & \multicolumn{8}{|c|}{ 'Khankayskiy 429' } \\
\hline & 2011 & 3750 & 2060 & 54.9 & 2410 & 64.3 & -720 & -19.2 \\
\hline & 2012 & 4830 & 1810 & 37.5 & 3520 & 72.9 & -500 & -10.4 \\
\hline & 2013 & 5598 & 560 & 10.0 & 5460 & 97.5 & -422 & -7.5 \\
\hline & average & 4726 & 1476 & 31.3 & 3797 & 80.3 & -547 & -11.6 \\
\hline & \multicolumn{8}{|c|}{ 'Rassvet' } \\
\hline & 2011 & 3010 & 1560 & 51.8 & 2170 & 72.1 & -720 & -23.9 \\
\hline & 2012 & 4180 & 1560 & 37.3 & 3120 & 74.6 & -500 & -11.9 \\
\hline & 2013 & 5198 & 530 & 10.2 & 5090 & 97.9 & -422 & -8.1 \\
\hline & average & 4129 & 1216 & 29.4 & 3460 & 83.8 & -547 & -13.2 \\
\hline \multirow{10}{*}{$\begin{array}{l}\text { Variant } 2: \\
80 \% \text { of FMC, } \\
0.4 \text { and } 0.6 \mathrm{~m}\end{array}$} & \multicolumn{8}{|c|}{ 'Khankayskiy 429' } \\
\hline & 2011 & 3780 & 2160 & 57.1 & 2410 & 63.8 & -790 & -20.9 \\
\hline & 2012 & 5040 & 2160 & 42.8 & 3520 & 69.8 & -640 & -12.6 \\
\hline & 2013 & 5646 & 690 & 12.2 & 5460 & 96.7 & -504 & -8.9 \\
\hline & average & 4822 & 1670 & 34.6 & 3797 & 78.7 & -645 & -13.3 \\
\hline & \multicolumn{8}{|c|}{ 'Rassvet' } \\
\hline & 2011 & 3200 & 1820 & 56.9 & 2170 & 67.8 & -790 & -24.7 \\
\hline & 2012 & 4300 & 1820 & 42.3 & 3120 & 72.5 & -640 & -14.8 \\
\hline & 2013 & 5306 & 800 & 15.1 & 5010 & 94.4 & -504 & -9.5 \\
\hline & average & 4269 & 1480 & 34.7 & 3434 & 80.4 & -645 & -15.1 \\
\hline \multirow{10}{*}{$\begin{array}{l}\text { Variant 3: } \\
80 \% \text { of FMC, } \\
0.6 \mathrm{~m} \\
\text { (control) }\end{array}$} & \multicolumn{8}{|c|}{ 'Khankayskiy 429' } \\
\hline & 2011 & 4420 & 2380 & 53.8 & 2410 & 54.5 & -370 & -8.3 \\
\hline & 2012 & 5780 & 2380 & 41.1 & 3630 & 62.8 & -230 & -3.9 \\
\hline & 2013 & 6190 & 680 & 11.0 & 5460 & 88.2 & 50 & 0.8 \\
\hline & average & 5463 & 1813 & 33.2 & 3833 & 70.1 & -183 & -3.3 \\
\hline & \multicolumn{8}{|c|}{ 'Rassvet' } \\
\hline & 2011 & 4010 & 2040 & 50.9 & 2340 & 58.3 & -370 & -9.2 \\
\hline & 2012 & 4930 & 2040 & 41.4 & 3120 & 63.2 & -230 & -4.6 \\
\hline & 2013 & 5820 & 680 & 11.7 & 5090 & 87.5 & 50 & 0.8 \\
\hline & average & 4920 & 1587 & 32.3 & 3516 & 71.4 & -183 & -3.7 \\
\hline
\end{tabular}


In structure of the total water consumption of rice varieties under different irrigation regimes, share of atmospheric moisture over whole growing season in 2011 was $54.5 \ldots 72.1 \%$, in $2012-62.8 \ldots 74.6 \%$, in $2013-87.5 \ldots 97.9 \%$. The results of field studies showed that soil moisture is used only in the initial period of rice development, and it accounts for about $1 \%$ of total water consumption. The share of irrigation water in the structure of rice total water consumption varied $10.0-15.1 \%$ (in 2013) to $50.9 \ldots 57.1 \%$.

The results of the research showed that the optimal parameters of rice irrigation regime during sprinkling are formed under differentiated moistening: maintaining the pre-irrigation humidity at level more than $75 \%$ of $\mathrm{FMC}$ in $0.4 \mathrm{~m}$ layer during the sowing - tillering period, in $0.6 \mathrm{~m}$ layer - at level more than $85 \%$ of FMC during tillering - wax ripeness of grain, which contributes to reduction of irrigation water costs for obtaining projected grain yield.

The water balance of rice card-check is represented by income and expense items. In the incoming part there is an irrigation norm, which is supplied to maintain necessary water layer in checks, and precipitation. The expenditure part includes balance items used to maintain water layer in checks, water consumption, filtration, leakage, flow, and technological water removing.

In structure of water balance of irrigation card-check, the largest water consumption was $4,224 \mathrm{~m}^{3} /$ ha of expenditure part in the first variant of shortened flooding in cultivar 'Khankayskiy 429'.

The lowest water consumption was noted in the second variant of intermittent flooding in 'Rassvet' cultivar and amounted to $2,859 \mathrm{~m}^{3} /$ ha of expenditure part.

The main indicators of water balance of card-check in experiment variants did not change significantly. The filtration was $1,726 \ldots 2,480 \mathrm{~m}^{3} /$ ha of expenditure part. The flow rate for water was $417 \ldots 631 \mathrm{~m}^{3} /$ ha in the first variant with shortened flooding. The volume of technological water removing varied from 3,200 to $4,367 \mathrm{~m}^{3} /$ ha on average over the research years (Table 3).

The highest irrigation rates $12,534 \mathrm{~m}^{3} /$ ha and $11,249 \mathrm{~m}^{3} /$ ha were established in the third variant with intermittent flooding for 'Khankayskiy 429' and 'Rassvet', respectively. The lowest irrigation rates were established at shortened flooding regime $\left(9,811 \mathrm{~m}^{3} / \mathrm{ha}\right.$ and $8,758 \mathrm{~m}^{3} /$ ha for 'Khankayskiy' and 'Rassvet' cultivars, respectively), which is connected primarily with check flooding scheme and water layer.

The study of influence of seed rates on rice yield showed that the maximum yield was obtained at a rate of 5 million seeds. Increase in seed rate resulted in high plant density which consequently led to yield decrease.

Cultivating 'Volgogradskiy' rice cultivar under sprinkling irrigation with $80 \%$ of FMC, applying mineral fertilizers $\mathrm{N}_{120} \mathrm{P}_{30} \mathrm{~K}_{30}$ and at seeding rate of 5 million seeds, yield was $4.6 \mathrm{t} / \mathrm{ha}$.

Depending on soil and climatic factors and factors studied, Primorsky rice cultivars formed the following grain yields: 'Dariy 23' (3.52 t/ha), 'Priozerny 61' (3.85 t/ha), 'Rassvet' (sprinkling — 4.19 t/ha, shortened flooding — 5,4 t/ha), 'Lugovoy' (4,2 t/ha), 'Kaskad' (sprinkling — 4.8 t/ha, flooding — 5.5 t/ha), 'Khankayskiy 429' (sprinkling $4.38 \mathrm{t} / \mathrm{ha}$, intermittent flooding of the IV type - 5.6 t/ha) [8-10]. The optimum time for rice sowing — 20 to 25 May — was established in the southern zone of Amur Region. 
Table 3

Water balance of card-check under different regimes of rice flooding, average for 2011-2013

\begin{tabular}{|c|c|c|c|c|c|c|}
\hline \multirow[t]{4}{*}{ Indicators } & \multicolumn{6}{|c|}{ Cultivar } \\
\hline & \multicolumn{3}{|c|}{ 'Khankayskiy 429' } & \multicolumn{3}{|c|}{ 'Rassvet' } \\
\hline & \multicolumn{6}{|c|}{ irrigation regime } \\
\hline & 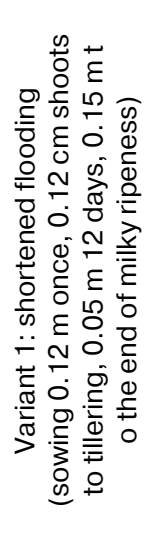 & 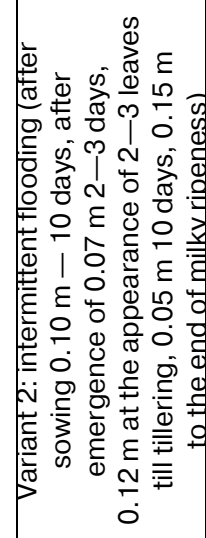 & 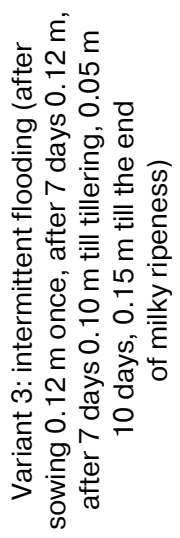 & 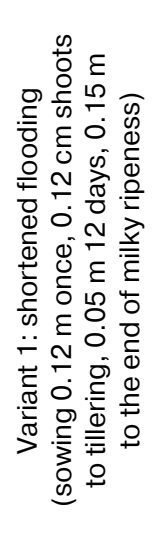 & 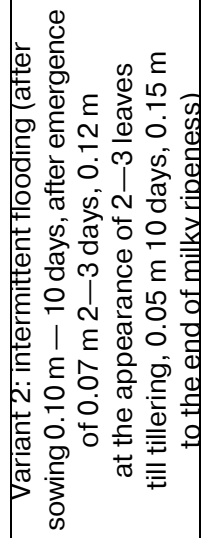 &  \\
\hline \multicolumn{7}{|c|}{ Water input, $\mathrm{m}^{3} / \mathrm{ha}$} \\
\hline Irrigation Rate & 9811 & 11786 & 12534 & 8758 & 9543 & 11249 \\
\hline Precipitation & 4250 & 4243 & 4237 & 3697 & 3720 & 3907 \\
\hline Total & 14061 & 16029 & 16788 & 12455 & 13263 & 15156 \\
\hline \multicolumn{7}{|c|}{ Expenditure water, $\mathrm{m}^{3} / \mathrm{ha}$} \\
\hline $\begin{array}{l}\text { Maintaining } \\
\text { water level }\end{array}$ & 2200 & 4600 & 4300 & 2200 & 3900 & 4333 \\
\hline $\begin{array}{l}\text { Change in mois- } \\
\text { ture reserves in } \\
\text { aeration zone }\end{array}$ & -254 & -146 & -136 & -254 & -146 & -136 \\
\hline Filtration & 2470 & 2201 & 2480 & 2015 & 1726 & 1846 \\
\hline $\begin{array}{l}\text { Water } \\
\text { consumption }\end{array}$ & 4224 & 3705 & 3870 & 3470 & 2859 & 3201 \\
\hline Leakage loss & 651 & 614 & 693 & 567 & 459 & 574 \\
\hline Flowing & 591 & 543 & 631 & 515 & 417 & 523 \\
\hline $\begin{array}{l}\text { Technological } \\
\text { water removing }\end{array}$ & 3333 & 3967 & 4367 & 3200 & 3400 & 4367 \\
\hline Total & 13723 & 15776 & 16477 & 12221 & 12907 & 14980 \\
\hline $\begin{array}{l}\text { Discrepancy, } \\
\mathrm{m}^{3} / \mathrm{ha}\end{array}$ & 338 & 254 & 311 & 234 & 356 & 176 \\
\hline Discrepancy, \% & 2.4 & 1.6 & 1.8 & 1.8 & 2.7 & 1.2 \\
\hline
\end{tabular}

\section{CONCLUSIONS}

The possibility of rice cultivation is proved on the basis of effective use of irrigation water by optimizing water regime of soil. When sprinkling under conditions of the southern zone of Amur Region, optimal regimes were: differential irrigation regime with $75 \ldots 85 \%$ of FMC in 0.4 and $0.6 \mathrm{~m}$ active soil layer, intermittent flooding of the 
IV type of cultivar 'Khankayskiy 429' and shortened flooding of 'Rassvet' cultivar. Grain rice yield of more than 4 tons/ha is achieved by application of mineral fertilizers in the rate $\mathrm{N}_{120} \mathrm{P}_{30} \mathrm{~K}_{30}$ and seeding rate of 5 million seeds. The optimal sowing time was also identified - May 20-25.

(C) E.P. Borovoy, M.V. Makannikova, L.A. Lapshakova, 2018.

\section{REFERENCES}

[1] Krivolapov IE. Ris na Dal'nem Vostoke [Rice in the Far East]. Vladivostok: Dal'nevostochnoe Publ.; 1971. 315 p. (In Russ).

[2] Borodin IV. Vyzrevanie risa na Amure v zavisimosti ot sposobov poliva [Ripening of rice on Amur depending on irrigation methods]. Vladivostok: Dalgiz Publ.; 1933. 40 p. (In Russ).

[3] Neunylov BA. O risoseyanii na yuge Khabarovskogo kraya i Amurskoi oblasti. Pochvy risovykh polei Dal'nego Vostoka [Rice cultivation in the south of Khabarovsk Territory and Amur Region. Soils of rice fields in the Far East]. Vladivostok; 1980. 156 p. (In Russ).

[4] AgroMax. Not all rice is Primorsky. Press-sluzhba Primorskogo kraya. 2009, September: No. 2. (In Russ).

[5] Dospekhov BA. Planirovanie polevogo opyta i statisticheskaya obrabotka ego dannykh [Planning of field experiment and statistical processing of its data]. Moscow: Kolos Publ.; 1972. 207 p. (In Russ).

[6] Zaitseva VB, editor. Metodika gidromeliorativnykh issledovanii pri oroshenii risa [Technique of hydro-reclamation research in rice irrigation]. Krasnodar: VNII risa Publ.; 1977. 109 p. (In Russ).

[7] Kruzhilin IP, Melikhov VV, Ganiev MA, Bolotin AG. Tekhnologiya vozdelyvaniya malovodotrebovatel'nogo risa pri dozhdevanii v Nizhnem Povolzh'e. Rekomendatsii [Technology of cultivation of low-water-demand rice under sprinkling in Lower Volga Region. Recommendations].Volgograd; 2004. 24 p. (In Russ).

[8] Makannikova MV, Borovoi EP. Irrigation regime and water consumption of rice in the southern zone of the Amur Region. Izvestiya Nizhnevolzhskogo agrouniversitetskogo kompleksa: nauka i vysshee professional'noe obrazovanie. Sbornik nauchnykh trudov. 2013;29(1):91—95. (In Russ).

[9] Lapshakova LA, Makannikova MV. Assessment of rice yield under different irrigation regimes in the southern agricultural zone of the Amur Region.Vestnik KrasGAU. 2016;116(5):165172. (In Russ).

[10] Makannikova MV, Lapshakova LA, Dontsov PA. Optimization of irrigation regimes of rice in conditions of the Middle Amur Region. Nauchnaya zhizn'. 2016;(5):69-76. (In Russ).

\section{Author's personal data:}

Evgeny Pavlovich Borovoi - Doctor of Agricultural Science, Professor, Head of the Department of Land Reclamation of Volgograd State Agricultural University; e-mail: borovoy.e.p@mail.ru

Marina Vasilievna Makannikova - Candidate of Agricultural Science, Associate Professor of Far East State Agrarian University; e-mail: giz@dalgau.ru

Larisa Alexandrovna Lapshakova - Candidate of Engineering Science, Associate Professor of Far East State Agrarian University; e-mail: giz@dalgau.ru

\section{For citation:}

Borovoy E.P., Makannikova M.V., Lapshakova L.A. Rice cultivation in Amur region. RUDN Journal of Agronomy and Animal Industries, 2018, 13 (3), 207-215. doi: 10.22363/2312-797X2018-13-3-207-215. 


\title{
ОСОБЕННОСТИ ВОЗДЕЛЫВАНИЯ РИСА В УСЛОВИЯХ АМУРСКОЙ ОБЛАСТИ
}

\author{
Е.П. Боровой ${ }^{1}$, М.В. Маканникова ${ }^{2}$, \\ Л.А. Лапшакова ${ }^{2}$ \\ ${ }^{1}$ ФГБОУ ВО Волгоградский государственный аграрный университет \\ nр. Университетский, 26, Волгоград, 400002, Российская Федераџия \\ ${ }^{2}$ ФББОУ ВО Дальневосточный государственный аграрный университет \\ ул. Кузнечная, 95, Благовещенск, 675000, Российская Федерачия
}

В статье представлены результаты исследований возделывания риса при разных режимах орошения (70, 80, 90\% НВ). В условиях южной зоны Амурской области также были изучены режимы орошения риса, сочетающие в себе дифференцирование предполивных порогов влажности и глубины промачивания активного слоя почвы 75-85\% HB (0,4 и 0,6 м); 80\% НВ (0,4 и 0,6 м). Кроме того, были изучены разные режимы затопления рисового поля слоем воды (укороченное и прерывистое затопление), нормы высева семян, сроки сева, сорта риса. Получение урожайности зерна риса более 4 т/га обеспечивается внесением минеральных удобрений в дозе $\mathrm{N}_{120} \mathrm{P}_{30} \mathrm{~K}_{30}$ и нормой высева 5 млн всхожих семян. Оптимальные сроки сева были установлены с 20 по 25 мая. По результатам исследований, за счет проведения оптимизации режимов орошения риса в условиях дождевания, посредством дифференцирования предполивных порогов влажности и глубин промачивания наблюдалась экономия оросительной воды и увеличение урожайности. При возделывании риса в условиях затопления было установлено, что оптимальными считаются режим укороченного затопления.

Ключевые слова: рис, водные режимы, дождевание, затопление, дозы удобрений, нормы высева, сорта

\section{БИБЛИОГРАФИЧЕСКИЙ СПИСОК}

[1] Криволапов И.Е. Рис на Дальнем Востоке / И.Е. Криволапов. Владивосток: Дальневост. кн. изд-во, 1971.

[2] Бородин И.В. Вызревание риса на Амуре в зависимости от способов полива / И.В. Бородин. Владивосток: Дальгиз, 1933.

[3] Агромакс / Не весь рис - Приморский // Пресс-служба Приморского края. № 1, сентябрь 2009.

[4] Неунылов Б.А. О рисосеянии на юге Хабаровского края и Амурской области // Почвы рисовых полей Дальнего Востока. Владивосток, 1980.

[5] Доспехов Б.А. Планирование полевого опыта и статическая обработка его данных. М.: Колос, 1972.

[6] Методика гидромелиоративных исследований при орошении риса / под ред. В.Б. Зайцева. ВНИИ риса. Краснодар, 1977.

[7] Кружилин И.П., Мелихов В.В., Ганиев М.А., Болотин А.Г. Технология возделывания маловодотребовательного риса при дождевании в Нижнем Поволжье / Рекомендации. Волгоград, 2004.

[8] Маканникова М.В. Режим орошения и водопотребление риса в условиях южной зоны Амурской области / М.В. Маканникова, Е.П. Боровой // Известия Нижневолжского агроуниверситетского комплекса: наука и высшее профессиональное образование. Сб. научн. трудов. Волгоград: Изд. ВолГАУ, 2013. № 1 (29). С. 91—95. 
[9] Лапшакова Л.А. Оценка урожайности растений риса при различных режимах орошения в условиях южной сельскохозяйственной зоны Амурской области / Л.А. Лапшакова, М.В. Маканникова // Вестник КрасГАУ. 2016. № 5. С. 165-172.

[10] Маканникова М.В. Оптимизация режимов орошения риса в условиях Среднего Приамурья / М.В. Маканникова, Л.А. Лапшакова, П.А. Донцов // Научный журнал «Научная жизнь». Москва, 2016. № 5. С. 69-76.

\section{Для цитирования:}

Боровой Е.П., Маканникова М.В., Лапшакова Л.А. Особенности возделывания риса в условиях амурской области // Вестник Российского университета дружбы народов. Серия: Агрономия и животноводство. 2018. Т. 13. № 3. С. 207-215. doi: 10.22363/2312-797Х-2018-13-3-207-215. 